\title{
Exploring the Development and Transfer of Career Capital in an International
}

\section{Governmental Organization}

\section{Abstract}

This study investigates global career self-management behaviors of staff in an international governmental organization (IGO). The literature on global careers argues that individuals should maximize their career capital, operationalized in the intelligent careers (IC) concept as competencies, social networks and motivations of persons related to their careers. The IC concept implies that career capital is transferable and argues that IC components are interrelated and self-reinforcing. We explored these assumptions through a case study in a United Nations (UN) organization. Using the IC framework we undertook 29 semi-structured interviews with international assignees, HR and operational experts and conducted one focus group discussion with seven staffing coordinators. We found that the UN organization had high barriers to career capital transfer between head office and field stations. Therefore, the IGO staff experienced conflicting demands in terms of their career capital behaviors. Many staff did not focus on maximizing their career-relevant capabilities or social networks. Instead, they pursued international careers that intentionally sacrificed internal career progression in favor of their humanitarian aid duties. The research adds to the insights of the global careers literature and refines our understanding of the relationship of the organizational center to its foreign affiliates. The findings expose potentially contradictory behavioral implications of elements of the IC concept and call for a context-sensitive refinement. Managerial implications for resourcing, development, career management and retention are discussed.

Keywords: global careers, intelligent careers, international mobility, international governmental organizations, head office - subsidiary relationship 


\section{Exploring the Development and Transfer of Career Capital in an International}

\section{Governmental Organization}

\section{Introduction}

Individuals around the world are urged to pursue an 'intelligent career' (Parker, Khapova \& Arthur, 2009). The IC concept is based on the explicit assumption that careerists should maximize their competencies, invest in their self-understanding and motivation and build their social networks in order to further their careers (Inkson \& Arthur, 2001). Individuals invest in their 'career capital' - consisting of knowing how, why and whom - which is seen as selfreinforcing and transferrable (Jokinen, 2010; Lamb \& Sutherland, 2010). However, the inherent tensions of maximizing these three ways of knowing (DeFillippi \& Arthur, 1994) as well as potential threats to transferability and self-reinforcement have so far been neglected in the literature. This article will outline these tensions through the exploration of the attitudes and behaviors of globally mobile professionals. In so doing, it refines intelligent career ideas and participates in the debate on new careers (Lips-Wiersma \& Hall, 2007; Tams \& Arthur, 2010) and modern global careers (Shaffer, Kraimer, Chen \& Bolino, 2012).

Modern global careers are predominantly explored using a perspective in which individuals direct their careers (Al Ariss \& Syed, 2011; Shaffer et al., 2012). The IC concept is strongly linked to the boundaryless careers discussion (Arthur \& Rousseau, 1996; Sullivan \& Arthur, 2006) and due to the implied move across borders, particularly suited to exploration of international careers (Haslberger \& Brewster, 2009; Jokinen, Brewster \& Suutari, 2008). Its conceptualization goes beyond an identity perspective to incorporate social capital as well as capabilities and links into a wide range of academic perspectives which enable a broad understanding of career behaviors (Parker et al., 2009). 


\section{DEVELOPMENT AND TRANSFER OF CAREER CAPITAL}

Much has been written about careerists and what impact international work can have on their careers, identities, behaviors and career success (Cappellen \& Janssens, 2010; Lazarova \& Cerdin, 2007; Yan, Zhu, \& Hall, 2002; Biemann \& Braakmann, 2013). However, Oberholster, Clarke, Bendixen and Dastoor (2013) as well as Brewster and Suutari (2005) argue that most careers and global mobility research has focused on multinational corporations (MNCs) to the detriment of knowledge about humanitarian non-profit organizations or international governmental organizations (IGOs). There is little doubt that most IGOs are highly international and that professional staff are often pursuing global careers (Baruch, Dickmann, Altman \& Bournois, 2013), therefore it is timely to explore cross-border careers in IGOs in more depth.

Organizational, structural and operational differences between MNCs and IGOs as well as international non-governmental organizations (INGOs) can be large (Lindenberg \& Bryant, 2001). Being close to the corporate center is often beneficial for the acquisition of knowledge and career progression in MNCs (Baruch and Altman, 2002; Mäkelä, Björkman, \& Ehrnrooth, 2009) but this is less clear for individuals working in the field (Ahmad, 2007). The differences between the center of the organization and its operational delivery in IGOs and INGOs are likely to have negative implications for the transferability of competencies (Toomey, 2010). The motivation of staff in IGOs and INGOs is more likely to be altruism (Oberholster et al., 2013; Emmerik \& Eumewa, 2009) or a dedication to a cause (Cerdin \& Dickmann, 2011). As this cause can appear closest in the field, potential choices between motivational drivers and objective career benefits might be stark (Hudson \& Inkson, 2006). Researching global careers in an IGO does, therefore, not only fill an empirical gap, it also allows us to explore (and potentially challenge) key assumptions of the intelligent career concept (Piekkari, Welch, \& Paavilainen, 2009). Do individuals in IGOs take up the call to maximize knowing how, knowing why and knowing whom and are these self-reinforcing and transferable? 


\section{DEVELOPMENT AND TRANSFER OF CAREER CAPITAL}

This paper investigates the career self-management behaviors of internationally mobile staff in the head office and field stations of an IGO with a specific focus on the development and transfer of career capital. The discussion and conclusions illuminate the importance of organizational context and individual career self-management behaviors. One contribution is that key insights from the global careers and international mobility literatures cannot be extended to this IGO. Another contribution of this study is to urge the refinement of the IC concept to more strongly reflect context and the possibility that the three career capital areas may imply contradictory behavior.

\section{Modern Careers}

Careers can be defined as "patterns of work-related experiences that span the course of a person's life" (Greenhaus, Callanan, \& Godshalk, 2010, p. 9). Protean and boundaryless career ideas have dominated much of the career research in recent years (Sullivan \& Baruch, 2009). Protean careerists are the driving forces of their own careers in the pursuit of their need for self-fulfillment (Hall, 1976, 1996). Like the Greek god Proteus, they are able to change their shape which is taken to mean that they can react flexibly to a dynamic environment and rearrange and fit their competencies to the needs of their work. Granrose and Baccili (2006) see both protean and boundaryless career patterns concurrently.

The boundaryless career (Arthur \& Rousseau, 1996, p. 9) challenges the concept of 'traditional organizational career arrangements'. While it is clear that boundaries to careers continue to exist (Sullivan \& Baruch, 2009; Zikic, Bonache, \& Cerdin, 2010), the approach focuses on how individuals can move across physical work boundaries such as separate employers or national borders. In addition, boundaryless career moves also include changes in psychological boundaries such as the consideration of lateral over hierarchical job moves (Arthur, Khapova, \& Wilderom, 2005; Sullivan \& Arthur, 2006). The boundaryless career 


\section{DEVELOPMENT AND TRANSFER OF CAREER CAPITAL}

perspective incorporates a protean orientation, next to career competencies and multidirectional mobility patterns as outlined by Greenhaus, Callanan and DiRenzo (2008). For an in depth review, see Sullivan and Baruch (2009).

Given the breadth of the concept, it is no surprise that the boundaryless career paradigm is one of the most prevalent theoretical approaches in expatriation research (Shaffer et al., 2012, p. 1288; Andresen, Biemann \& Pattie, 2015). The IC concept is built on boundaryless career ideas (Cerdin \& Bird, 2008; Haslberger \& Brewster, 2009) and often used in expatriation research (Yao, 2014; Jokinen, 2010; Jokinen et al., 2008). The intelligent career (IC) concept is well suited for the exploration of modern global careers (Suutari \& Mäkelä, 2007).

\section{Global Intelligent Careers}

The IC concept was developed by DeFillippi and Arthur (1994) as a response to intelligent enterprise ideas (Quinn, 1992). While there are other forms of career capital e.g., symbolic career capital (Bourdieu, 1986; Lamb \& Sutherland, 2010), the intelligent career approach normally distinguishes three ways of knowing (Haslberger \& Brewster, 2009).

First, knowing how career capital refers to skills, expertise, tacit and explicit knowledge and other work-related capabilities (Inkson \& Arthur, 2001; Khapova, Arthur \& Wilderom, 2007) that individuals accumulate and draw from in their careers. These skills may be technical, inter-personal or cognitive (Jokinen et al., 2008; Lamb \& Sutherland, 2010) and have an impact on carrying out work and on career advancement.

Second, knowing why career capital describes the energy, motivation, sense of purpose and identification that individuals invest in their work life (Arthur, Claman \& DeFillippi, 1995). These are based on the interests, values and meanings that individuals attach to their careers (Jones \& Lichtenstein, 2000). Considerations of work-life balance and identity issues as well as understanding one's own beliefs, cultural background and developmental goals, are 


\section{DEVELOPMENT AND TRANSFER OF CAREER CAPITAL}

part of knowing why (Jokinen et al., 2008; Kohonen, 2005). Family issues and personal drivers are part of the concept because knowing why is strongly linked to values and identity (Haslberger \& Brewster, 2009; Suutari \& Mäkelä, 2007).

Third, knowing whom career capital relates to the networks, personal reputation, sources of information and mutual obligations that careerists gather (Parker et al., 2009). From a professional perspective this would incorporate relationships with superiors, peers and subordinates; but these extend to business contacts outside the organization and other social relationships (Lamb \& Sutherland, 2010). Working abroad, authors have researched home, host and international networks (Dickmann \& Doherty, 2008) with some writers also distinguishing social capital internal and external to the organization (Jokinen et al., 2008).

The IC concept incorporates an identity perspective as well as career-relevant knowledge, skills, abilities and networks. Career capital is strongly linked to modern career outcomes (Bagdadli, Solari, Usai \& Grandori, 2003; Shaffer et al., 2012; Wolff \& Moser, 2009) and enables the use of multiple perspectives to increase our understanding of modern careers (Parker et al., 2009).

\section{Global IC and the Role of Head Office and Foreign Affiliates}

In this section, we explore the literature on international work while focusing on the context and roles of head office and foreign affiliates in relation to the IC concept. In each of the three ways of knowing we distinguish career capital development patterns in head office and foreign affiliates and discuss transferability implications.

Knowing how effects of working in head office or foreign affiliate locations. International assignments aiming at management development can refine knowing how career capital in relation to technical competencies, global business acumen, organizational and 


\section{DEVELOPMENT AND TRANSFER OF CAREER CAPITAL}

intercultural knowledge (Haslberger \& Brewster, 2009; Thomas \& Inkson, 2004). In addition, Maddux, Adam \& Galinsky (2010) argue that living in and adapting to a foreign context can enhance creativity. Working abroad is seen to result in general global competencies (Caligiuri \& Di Santo, 2001).

Filling positions abroad with head office technical or functional experts (Caligiuri, 2012) assumes that the available skills, knowledge and abilities in the head office are higher and that they are transferable (Edwards, Colling, \& Ferner, 2007; Jokinen, 2010). Global careerists benefit from using their competencies in a different cultural and institutional context and by refining them through adapting to their new environment (Dickmann \& Harris, 2005; Haslberger \& Brewster, 2009). In turn, cross-border moves to the organizational center (inpatriation) allow global careerists to understand and absorb the MNC's head office culture and to learn leading-edge company approaches and strategies (Mäkelä et al., 2009; Reiche, Kraimer, \& Harzing, 2011).

Wherever the move, the acquired knowing how would need to be transferrable between head office and foreign affiliates in order to have positive long-term work outcomes (Jokinen et al., 2008). Individuals would benefit from transferring their learning to reach a higher competency level in the following location, to be seen to grow as a leader, to perform well and to increase their promotion prospects (Doherty \& Dickmann, 2012). Knowing how capabilities - at times depending on the context - are generally seen as transferable even though some were more readily useable than others (Jokinen, 2010).

Knowing why effects of working in head office or foreign affiliate locations. There is extensive literature that identifies reasons and barriers to working abroad (Boies \& Rothstein, 2002; Hippler, 2009; Tung, 1998; Caligiuri \& Tarique, 2009). International work has the capacity to develop an individual's identity and future career aspirations (Kohonen, 2005). 


\section{DEVELOPMENT AND TRANSFER OF CAREER CAPITAL}

Expatriate work affects the individual's sense of self and impacts their behaviors and attitudes towards their employers (Andreason \& Kinner, 2005; Kraimer, Shaffer, Harrison \& Ren, 2012). Inpatriation - a move of a foreign national to the organization's head office - primarily serves as a developmental relocation with the resulting focus on individual learning (Baruch et al., 2013). Inpatriates are expected to adapt to the head office as well as to the host country culture and have a higher need for collaboration with their colleagues (Reiche et al., 2011). Given the potentially strong cultural effects of head offices on organizational culture and its importance to knowing why (Bartlett \& Ghoshal, 1998; DeFillippi \& Arthur, 1994), working at the head office is likely to have a strong knowing why impact.

Transferability of knowing why is related to how well work serves personal drivers over time. While the motivational considerations of individuals are highly diverse, it seems that working in head offices can show a stronger alignment on some key drivers. Academic work has shown that amongst the key interests of expatriates are developmental and career considerations (Reiche et al., 2011; Dickmann, Doherty, Mills and Brewster, 2008). Where the head office is perceived as good for professional development and career advancement (Newell \& Dopson, 1996; Dickmann \& Doherty, 2010), a move into the organizational center may be more in-line with many individuals' professional knowing why considerations than a move away from it. The identity of an individual is also connected to social capital (Ibarra \& Deshpande, 2007) and knowing whom as explored by Arthur and his colleagues (Inkson \& Arthur, 2001; Parker et al., 2009).

Knowing whom effects of working in head office or foreign affiliate locations. All forms of international mobility can build employees' social ties within MNCs (Bozkurt \& Mohr, 2011). Expatriates function as knowledge brokers and transmitters (Reiche, Harzing \& Kraimer, 2009; Farh, Bartol, Shapiro \& Shin, 2010) and expatriate managers from the head 


\section{DEVELOPMENT AND TRANSFER OF CAREER CAPITAL}

office benefit organizations through high levels of cross-unit social capital (Mäkelä et al., 2009). Social networks allow expatriates to better relate and connect with others (Toh \& DeNisi, 2007), ultimately supporting their adjustment (Haslberger, 2005; Wang \& Kanungo, 2004).

The knowing whom impact on internal career progression might depend on how the organization's career system works. Within organizations with informal career systems, social connections to influential people in the head office help to secure continued employment or promotions (Dickmann \& Doherty, 2010). Working in the head office or having strong ties to head office staff can be highly important for individuals who pursue traditional hierarchical careers (Cappellen \& Janssens, 2010).

The transferability of knowing whom is an important consideration in international moves. Expatriates are bound to expand their local networks (Bozkurt \& Mohr, 2011) be they internal or external to the organization (Mäkelä \& Suutari, 2013). Moreover, they are likely to meet more influential people than they would at home and may expand their international networks (Berthoin-Antal, 2001; Farh et al., 2010). However, their home networks may suffer the 'out of sight, out of mind' effect (Feldman \& Thomas, 1992; Benson \& Pattie, 2008) and the physical distance may mean that their home social capital suffers.

There are a number of patterns observable that point to remaining in head office as being a good approach to one's personal career capital. In the long-term it seems likely that in most cases knowing how and knowing why career capital benefits from staying or returning to head office. Knowing whom career capital development, in turn, seems to be related to the formality of the organizational career system.

Critical reflection on the IC concept in a global context. Career capitalists are urged to maximize their investments in each of the three ways of knowing (Inkson \& Arthur, 2001). 


\section{DEVELOPMENT AND TRANSFER OF CAREER CAPITAL}

While there is concern about the effects of expatriation on career consequences, better career capital is often associated with positive intrinsic and extrinsic career outcomes (Shaffer et al., 2012; Suutari \& Mäkelä, 2007). Beyond career capital development, it might be the degree of transferability of career capital to a new context that can impact these career outcomes. In other words; if the transferability of knowing how is poor, a repatriate may have a lesser chance of positive career outcomes (Kraimer et al., 2012; Lazarova \& Cerdin, 2007). In the same vein, an extension of host networks may not be beneficial for a repatriate's work in the home country. Lastly, if an expatriate's insights and motivational drivers are strongly linked to the host country, there may be a negative effect arising upon repatriation (Reiche et al., 2011; Richardson, 2009). Without the transferability of career capital between home and host locations, the assumption that 'more career capital is better' is compromised.

Underlying the IC concept is the self-reinforcing nature of the three ways of knowing (Khapova et al., 2007; Lamb \& Sutherland, 2010) in that an investment in one career capital area is seen to have positive effects on the other two ways of knowing. Inkson and Arthur (2001) outline a range of examples of how the three career capital areas have beneficial links to each other. However, this may underplay the potential situation where an investment in one area, say following one's dream to live in Brazil, may have detrimental effects on other areas (e.g., being away from the center-of-excellence in the organization). Both, transferability and reinforcement assumptions of the IC concept have been underexplored.

\section{Working Abroad in IGOs and MNCs}

In the third sector, as well as the UN, the increasing number of humanitarian emergencies and fluctuating funding needs create highly dynamic employment situations (Merlot \& De Cieri, 2012). On the face of it, therefore, individual careerists are subjected to dynamic employment situations and have had to invest in their career capital (Dickmann, Parry, Emmens \& 


\section{DEVELOPMENT AND TRANSFER OF CAREER CAPITAL}

Williamson, 2010). There are a range of differences to MNCs that may impact on the career self-management of IGO staff.

First, the strategic challenges that are perceived in the humanitarian sector in response to major crises are often substantially different from those of MNCs as these are more likely to be linked to surge capacity (Merlot \& De Cieri, 2012). In IGOs, the head office or regional centers are key to gaining funds or to political lobbying (Lindenberg \& Bryant, 2001; Merlot \& De Cieri, 2012) unlike MNCs which can gain resources through foreign operations. Therefore, for individuals who work in relief operations the actual activities that employees pursue in the field are often highly distinct. Knowing how in head offices and field stations varies substantially which makes an IGO likely to be a good case organization to examine the internal transferability of knowing how career capital.

Second, the management and behavior of IGOs, as well as other international non-profit organizations, are shaped to a higher degree by ideologies and values (Anheier \& Themudo, 2005) than those of MNCs. In addition, the context of the assignment may be quite different. IGOs such as UNDP (The United Nations' Development Programme), UNFAO (Food and Agriculture Organization) and UNWFP (World Food Programme) operate in highly dangerous and deprived countries such as Sudan (Darfur), Angola, Haiti or Afghanistan. Working in these circumstances requires highly dedicated staff and individuals are indeed driven by a different set of motivations in humanitarian agencies and IGOs compared to MNCs (Oberholster et al., 2013; Hudson \& Inkson, 2006). Oberholster and his colleagues found the key categories to work abroad in Christian humanitarian agencies were altruism, international experience and family life. Using an expanded notion of Schein's (1978) career anchors (Cerdin \& Le Pargneux, 2009) in an IGO, Cerdin and Dickmann (2011) showed that the three most important drivers for staff were lifestyle, dedication to a cause and pure challenge. These drivers varied substantially from those found for expatriates in MNCs especially when considering 


\section{DEVELOPMENT AND TRANSFER OF CAREER CAPITAL}

altruism/dedication to a cause. The IC concept prescribes the maximization and selfreinforcement of career capital areas irrespective of the specific knowing why drivers. IGOs may be good case organizations to investigate whether knowing how and knowing whom really reinforce knowing why capital in a context in which informal careers, with respect to pursuing own drivers, may be more important to actors than formal, hierarchical career notions (Hudson \& Inkson, 2006).

Third, in many MNCs expatriated managing directors, production engineers or finance directors carry on in their areas of expertise and have reasons to build knowing whom links to the head office. Conversely, in IGOs the degree of interaction with locals at the point of 'service delivery' is unusually high (Ahmad, 2007; Lindenberg \& Bryant, 2001) providing relatively more incentives to build local networks. These may be less portable and if careers are determined in the head office (Dickmann \& Doherty, 2008), less useful for promotions. IGOs are a good case to examine the transferability assumption of knowing whom capital.

\section{Exploring the Development and Transfer of Career Capital in an IGO}

Given that there is too little known about international HRM and careers in IGOs (Brewster \& Suutari, 2005; Toomey, 2010; Dabic, González-Loureiro \& Harvey, 2015) our research aimed to explore these issues in more depth. Using the intelligent careers concept our overarching research question was:

What guides the career self-management behaviors of internationally mobile staff in the head office and field stations in one IGO?

More specifically, we explored what knowing how, knowing why and knowing whom career capital internationally mobile staff in the head office and field stations of this IGO develop and how transferable this is within the organization. In so doing, 


\section{DEVELOPMENT AND TRANSFER OF CAREER CAPITAL}

we investigated whether some of the underlying assumptions of the IC concept also apply in this IGO.

\section{Research Background, Method and Process}

\section{Justification of Single Case Study}

Most case study research in international business use multiple case studies based on crosssectional designs and very few interviews per case thereby sacrificing the depth of holistic, contextual insights (Piekkari et al., 2009). Instead, we are looking to explore global career selfmanagement behaviors and to reflect on the IC concept with respect to its underlying assumptions. Case studies can be used to test theory (Bryman \& Bell, 2015). An IGO case has the ability to disconfirm or expand the IC concept due to the range of differences to MNCs outlined above. We use a 'deviant' case in which the characteristics and outcomes predicted may not occur, which may show the limits of generalizability or provide suggestions for further examination of problems (Emigh, 1997: p. 653-655) in relation to intelligent careers. A single case study design may lead to a paradigm challenge as it can depict contextual, rich insights well (Piekkari et al., 2009). The research used multiple data sources through a combination of the analysis of internal documents and a variety of expert and staff interviews as well as one focus group (Yin, 2009) to explore career self-management behaviors in terms of development and transfer of career capital.

\section{Case Organization and Sample}

The case organization was part of the United Nations which we describe as 'UNORG'. It had more than 10,000 employees and operated in 86 countries. More than $95 \%$ of its funds came from governments with seven percent used for UNORG's own cost of running operations. Its mission was related to providing humanitarian aid for crisis situations and developmental 


\section{DEVELOPMENT AND TRANSFER OF CAREER CAPITAL}

scenarios. Due to this, its main operations were in hardship duty stations. UNORG had more than 2,000 professional, degree-level staff for which it had career paths designed that normally started on P1 or P2 level and would rise to P5 level before converting into D1 (equivalent of country head or director of a function in head office).

All professional staff were expected to be internationally mobile. The HR director and some of her staff indicated in an interview that essentially everybody had at least one assignment outside the organizations' head office. Most professional staff spent their working lives away from the organizational center - maybe having one assignment to it - involved in delivering aid, local advice and sometimes, managing security. In contrast, some individuals spent most of their careers in the head office setting policy and operational guidelines and working on communication/advocacy. P2 and P3 level staff were likely to work as technical specialists with staff on or above P4 level most likely to be managers. In hardship duty stations assignments would normally last two years. UNORG attempted to have a maximum of two hardship stations followed by a family duty station in which staff would serve for four years. However, it was frequently the case that due to an emergency situation, professionals would work in foreign crisis areas for short times.

Like many case studies in international business, we based our research on the literature and specified a priori broad constructs to explore the career capital self-management behaviors in the IGO (Piekkari et al., 2009; Yin, 2009).

On the whole, the sample is made up of 36 UNORG employees. We conducted 13 indepth interviews with HR and operational experts, one focus group with seven staffing coordinators and assignee interviews with 16 professional staff in UNORG. The selection of the interviewees was non-random as we cooperated with the HR director and the professional staff association to draw up a list of employees who were highly diverse and had experience of working in different locations. While the organizational representatives aimed to achieve a 


\section{DEVELOPMENT AND TRANSFER OF CAREER CAPITAL}

sampling frame close to a quota sample, the realized sampling method was judgemental (Bryman \& Bell, 2015: 202-205; Stenhouse, 1980). Table 1 gives an overview and background of the assignee interviewees which shows that the interviews captured a variety of work functions, gender, age, location, family situation and hierarchical levels so as to elicit a wide variety of viewpoints.

\section{Insert Table 1 here}

\section{Data Collection}

The interview guide included the three career capital areas of the intelligent career approach. The assignee interviews lasted on average 75 minutes while the focus group lasted 2 hours. Expert interviews with HR managers (such as the HR director, deputy HR director and career management officer) served to understand the career system. Interviews with other experts (such as $\mathrm{COO}$ or staff representatives) allowed us to refine our understanding of the actual embedded career processes and individual behaviors within the organization. The focus group consisted of staffing coordinators who were in charge of professional resourcing decisions and had, therefore, exceptionally high insights into competencies and career behaviors of staff. Key to the focus group discussion was to understand the reality of career processes in UNORG. This involved an exploration of the way that staff coordinators made their decisions about assignment locations. Through the focus group discussion the researchers gained insights about promotion patterns and activities. In addition, locations that were beneficial to individuals' careers were identified and there was a discussion about what motivated UNORG staff members to join the organization and to work either in the head office or in duty stations. A strong undercurrent of the discussion was to investigate the transferability of acquired skills, insights and networks across duty stations and between head office and the field. The focus group, all expert interviews and four assignee interviews were conducted face to face in the 


\section{DEVELOPMENT AND TRANSFER OF CAREER CAPITAL}

head office. The other interviews were conducted over the telephone as these interviewees were working in 13 field stations in eleven countries. One interviewee from a field station happened to be in the head office and was interviewed there.

The expert interviews and document analysis showed that international HRM and amongst those, career and assignment systems, were centrally designed and key decisions were taken at the head office. UNORG used foreign assignments as a key social integration mechanism but also had bureaucratic controls in the form of resource allocations and reporting flows (Edwards et al., 2007). Promotion and assignment decisions were taken by central committees on the basis of written documents which did not allow career actors to represent their case in person.

\section{Data Analysis}

All interviews and the focus group discussions were recorded and transcribed. The expert interviews were summarized and sent to the Chief of Careers and another director of HRM (internally called $\mathrm{OMH}$ ) for verification of our understanding. A summary of the key points of the focus group discussion was sent to all members of the focus group for verification, two further points from their feedback incorporated and then sent out again for final verification. Given the small number of assignee interviews, we conducted a manual template analysis (King, 1998) using the following process to increase the quality of the analysis. The transcripts were read, analyzed and reviewed through an iterative process, independently, by two academics and the data were structured by recurrent patterns and organized into analytical themes. Data that was coded by the two academics in different ways was discussed using the whole interview transcript. In all but three cases of rival explanations (Yin, 2009) a joint decision as to the coding was possible. In these three cases we went back to the interviewees and clarified their statements. 


\section{DEVELOPMENT AND TRANSFER OF CAREER CAPITAL}

We used hierarchical coding with codes such as the three ways of knowing. Each career capital area would have sub-categories. For instance, knowing how distinguished a variety of technical, managerial, intra-organizational and cross-cultural capabilities (Caligiuri \& Di Santos, 2001; Thomas \& Inkson, 2004; Haslberger, Brewster and Hippler, 2013). Knowing why sub-categories included location, individual drivers, work-life balance, finance, development. Knowing whom sub-categories extended to home, host and international networks (Dickmann \& Baruch, 2011). These were defined as priori based on the literature and the interview questionnaire which is seen as one of the best starting points for constructing an initial template (King, 1998, p. 122).

Overall, we used multiple sources of evidence which served as a form of triangulation for the 16 staff interviewees' statements. Claims by assignees about career structures or processes in UNORG as well as statements with regards to transferable insights, or capabilities, or temporal dimensions of career progression, could be verified through access to UNORG data or expert commentary. A report to UNORG that was discussed in a one day workshop with HRM experts, official staff representatives and members of the staffing committee approximately six months after the research helped to verify our correct understanding of the UNORG career system. Basing the research design on the IC concept, using multiple sources of evidence, internal verification, pattern matching and explanation building increased the validity of our case approach (Yin, 2009). During the interviews we encouraged the interviewees to distinguish between head office and field station career capital effects.

\section{Findings}

\section{Careers in UNORG from the Organizational Perspective}

The organizational perspective was given by the HR team and by the focus group. The Head of HRM outlined that expatriation was a 'rite of passage' for all professional staff. They were 


\section{DEVELOPMENT AND TRANSFER OF CAREER CAPITAL}

'permanently mobile' and expected to 'share the burden' of working in the field (Deputy Head of HRM). In turn, everybody was expected to also work 'at least once in their career' in the head office (COO). In the focus group, career patterns (and perceptions) were outlined. There was agreement that 'once staff stay three years, they stay three decades' (Focus Group Statement). If professional employees left they would go to another UN family organization as 'the pay is so much lower in other agencies' and 'people running large multinationals are not interested in our capabilities' (Focus Group Statements). Our analysis, therefore, concentrated on career capital self-management geared towards work and internal career progression.

The findings of the interviews are presented below, organized into the three ways of knowing. In each of the career capital areas a table with quotes from interviewees linked to sub-categories is provided.

\section{Careers in the Head Office and Field: Knowing How Development and Transfer}

We have assessed technical competencies, organizational culture knowledge, intercultural competencies and global acumen (Haslberger et al., 2013; Thomas \& Inkson, 2004; Caligiuri \& Di Santo, 2001) in order to explore knowing how development. All professional staff felt that working in the field or in the head office was fundamentally distinct. Amongst the key areas of capability acquisition in the field were: local languages and customs, operational insights, technical skills, shaping government relations, the need to work independently from the reporting structure/boss, the ability to manage a large variety of stakeholders (some of whom may be hostile) and the use of diplomacy and tact. Importantly, nine individuals argued that they had little technical know how benefit from working in the head office that could be used in the field. This is in contrast to much of the literature that argues that expatriates have strong knowledge transfer and teaching roles which assumes that their knowledge is valuable in the operational context (Dowling, Festing \& Engle, 2008; Briscoe \& Schuler, 2004). Overall, 


\section{DEVELOPMENT AND TRANSFER OF CAREER CAPITAL}

it seemed that with the exception of logistics the operational demands in the field and head office were highly distinct (see Table 2).

The literature presumes that organizational culture know how is centered in the head office (Bartlett \& Ghoshal, 1998). In UNORG, nine interviewees argued that the true purpose of the IGO and its culture was linked to their humanitarian work and ultimately, to the field stations. Individuals felt that it was outside the head office that staff served the organization's core purpose. At times interviewees argued that it was not their actual work content but only the shared purpose that led to head office - field integration. The head office as the core originator and shaper of culture was being challenged.

\section{Insert Table 2 about here}

In addition, the assumption that expatriates improve their intercultural know how substantially by working abroad is also challenged in this IGO context (Haslberger et al., 2013; Dowling et al., 2008). A substantial minority of interviewees (six) voiced that they gained few, if any, cross-cultural managerial skills. Five people felt that they had a very international background before joining UNORG and brought it to the organization.

None of the interviewees were from the country in which the head office is located. Ten interviewees in UNORG pointed out, in various ways, that they had acquired global knowledge useful for understanding the broader context of aid provision from working in the head office. However, in marked contrast to the existing literature on MNCs (Edström \& Galbraith, 1977; Stahl, Miller \& Tung, 2002) it is not staff from head office who are bringing their superior operational capabilities or organization culture understanding to foreign affiliates - much of the skills, knowledge and abilities needed to deliver food aid are acquired in the field duty stations. 


\section{DEVELOPMENT AND TRANSFER OF CAREER CAPITAL}

The implications for the transferability of knowing how career capital were substantial. The interviewees argued that different learning opportunities existed and that diverse skill sets, survival skills and behaviors were needed in HQ and in the field. With the exception of global business acumen, the acquisition of know how was distinct from what the MNC literature indicated. Most technical capabilities were acquired by expatriates in the field who, in turn, often already had substantial cross-cultural skills. The interviewees argued that the necessary capabilities would be so distinct between the center and field duty stations as to have little overlap (the exception was logistics). Transferability of know how was highly limited.

\section{Careers in the Head Office and Field: Knowing Why Development and Transfer}

To assess knowing why effects, we explored personal interests and drivers, career and financial considerations, security and health concerns, family and life-balance issues, cross-cultural development and organizational pressures (Hippler, 2009; Stahl et al., 2002; Caligiuri \& Tarique, 2009). Fourteen interviewees indicated that the head office - field divide was substantial and that it had a key impact on their knowing why development (see Table 3). In terms of personal interests and drivers, working in the field was seen as more motivating and personally rewarding. The most frequently cited influence factors on the motivation to work abroad for UNORG were the humanitarian mission of the IGO, one's sense of meaningful work and seeing a difference made to people in need. Witnessing the effects of what can be done to help people was paramount for many people.

Eleven of the interviewees recognized that working in the field was detrimental to their internal career progression. Nevertheless, their personal drivers meant for most that they did not actively try to work in the head office. In terms of developmental considerations it has become clear that there was a strong differentiation between head office and field stations. It seems that the MNC literature indicates a higher importance of career and development 


\section{DEVELOPMENT AND TRANSFER OF CAREER CAPITAL}

considerations in the decision to work abroad (Dickmann et al., 2008; Hippler, 2009). Additionally, it was interesting that financial rewards were only mentioned by three respondents which again is at odds with the MNC literature on reasons to work abroad (Stahl et al., 2002).

Given the context in which UNORG is operating, it was no surprise that security and health considerations were important to almost all interviewees. In addition, the issue of isolation, often linked to being away from partners and family, was raised three times.

With respect to family and work-life balance issues, complex interactions existed (over time). Most interviewees (12) accepted going to non-family, hardship locations despite their families and the inherent security threat. Eight interviewees argued that work-life balance was very hard to achieve. Dual career issues, work-life balance considerations, local isolation and other context variables (e.g. schooling, hygiene, health provision) sometimes had the power to change the minds of professionals in UNORG so much so that four interviewees strove to work in family duty stations, occasionally including the head office. Two interviewees indicated that this wish to work in family duty stations was an effect of working in hardship locations, a development that would merit further research in the future.

\section{Insert Table 3 about here}

Many professional UNORG workers have decided that they would rather be close to the recipients of their aid than go and work in the head office. The interviews showed that in many cases the head office - field divide meant strong boundaries for the transfer of knowing why drivers. Beyond the difficulty of learning transfer between head office and duty stations, for two thirds of interviewees (11) it was predominantly their humanitarian drivers that constituted a massive barrier to transferring their knowing why into the head office. They 


\section{DEVELOPMENT AND TRANSFER OF CAREER CAPITAL}

simply felt more removed from the beneficiaries of their aid work and less motivated in the head office. The supposed benefits of inpatriation to the head office in MNCs (Reiche, 2006; Harvey, Speier \& Novicevic, 1999) were largely unattractive for them. In terms of further differences to individuals in MNCs, it may be said that in most cases their knowing why drivers were less linked to financial considerations or career progression (Stahl et al., 2002; Dickmann et al., 2008). This knowing why effect was in spite of many staff learning that social connections and superiors were highly important in UNORG.

\section{Careers in the Head Office and Field: Knowing Whom Development and Transfer}

We looked at home, host and international networks to assess knowing whom development (Dickmann \& Baruch, 2011). Career risks of working abroad can be substantial (Kraimer et al., 2012). In most organizations key career decisions relating to senior managers are taken in the center (McKinlay, 2002). This was not different in UNORG. In this IGO, social networks were used for a variety of purposes, including the use within selection (to specific locations), the use for access to specific jobs, the use to influence promotion decisions and the use to get things done. While the influence of the country director was also appreciated, 14 interviewees argued that the 'important' people for reassignment and career decisions were located in the head office and many would be members of the relevant career and assignment committees. Seven individuals adapted their behavior to increase their social ties with decision makers in head office.

While host country knowing whom was important to master one's work and to feel better adjusted (Toh \& DeNisi, 2007), 11 interviewees claimed that working in hardship locations would not result in adequate career recognition from the head office decision makers

(see Table 4). In contrast to much of the MNC literature that argues that individuals build their international networks when working abroad, a small majority of staff in the IGO (nine) stated 


\section{DEVELOPMENT AND TRANSFER OF CAREER CAPITAL}

that this would only be true of some key positions such as country directors. In general, it would be the head office staff who would add to their international contacts while foreign field station personnel would normally be highly engaged with local networks in their day-to-day work. Some field staff had adapted their behaviors and made more effort to build and maintain networks to key deciders in the head office which was affirmed by the focus group.

\section{Insert Table 4 about here}

Upon a further international move, staff would often be able to transfer knowing whom career capital in parts. They could use their head office and international networks especially for work purposes. Their host country networks, however, became far less valuable for doing their new jobs. The data on the head office - field station relationships and the diverse career capital effects has shown many differences between the case study IGO and what the literature generally describes about MNCs.

In summary, the UNORG case showed a number of surprising patterns. Unlike the predominant pattern in the MNC literature the knowing how development possible in the field station was distinct and difficult to transfer to the head office. Living the knowing why drivers and, at times, developing them, was far more likely in the field stations and most UNORG staff dreaded the prospect of working in the head office. This is in contrast to much of the inpatriation literature. In addition, there was a gulf with respect to the transferability of knowing why. In contrast, knowing whom development and transfer was most similar to that of MNCs with the possible exception of host country networks. The implications are discussed below.

\section{Discussion}

Working in the Head Office of the IGO is Beneficial for Internal Career Progression 


\section{DEVELOPMENT AND TRANSFER OF CAREER CAPITAL}

In the literature review we argued that in most cases working longer term in the head office is better for the individual's career especially when the MNC has an informal career system. It seems also important in the IGO to work in the head office for internal career progression due to the low transferability of competencies acquired in the field. Additionally, the strong importance of networks that influence assignment and promotion decisions points to the career benefits of working in the organizational center. This extends the argument from authors such as Lazarova and Cerdin (2007) and Reiche et al., (2011) as to the career importance of working in the head office to IGOs. However, a more detailed analysis within UNORG showed that the career capital impact of working in the field challenges many of the other insights from the MNC literature. This analysis is summarized in Table 5 and explored below.

\section{Career Capital Development in the Head Office and Foreign Duty Stations is Distinct}

In terms of knowing how we have a range of findings for UNORG that throw doubt on the generalizability of MNC insights to IGOs. First, many interviewees perceived that they acquired the necessary competencies to serve the organizational purpose in the field, exposing a stark divide to the head office. It appears that the organizational rationale of international coordination is less important in this IGO. In the IGO context the ideas of writers such as Bartlett and Ghoshal (1998), Harzing (1999) or Ferner and Edwards (1995) in terms of organizational integration mechanism, may be less applicable. Second, the literature is awash with ideas on how working abroad will improve the intercultural sensitivity and capabilities of individuals. This may be the case here too. However, it seems to be far less important due to the resourcing activities of this UN organization that selects many individuals who already have extensive cross-cultural skills. Third, the technical competences of the head office are not seen as better or useful to implement in the field - they are mostly regarded as radically distinct. In contrast, internationally posted personnel acquire many technical and job skills in the field. 


\section{DEVELOPMENT AND TRANSFER OF CAREER CAPITAL}

It supports the conclusions by Fee and Gray (2013) that knowing how acquisition by expatriates is unique in terms of context, process and outcomes. Jokinen (2010: p. 332) argues for 'conditional' transferability but here the context of MNC and IGO is so radically distinct that the transfer of knowing how is highly unlikely. This leads to the reversal of the argument that the center of operational excellence is often in the country where the organizational head office is located. It challenges much of the underlying assumptions of the organizational benefits of international knowledge transfer (Gupta \& Govindarajan, 2000; Sparrow, 2006). In addition, the operational task-related benefits for individuals were severely restricted as they found it hard to transfer their learning from head office to field station or the reverse (with the exception of logistics). Knowing how development in a duty station makes much more sense in terms of humanitarian aid delivery than in terms of career progression, a scenario that is not central to the IC framework in which individuals are career capitalists (Inkson and Arthur, 2001).

\section{Insert Table 5 about here}

In terms of knowing why, the majority of staff in the IGO did not feel motivated by working in the head office. They argued that it felt too detached from the mission and core operations of the organization. Main drivers for expatriates in MNCs, such as financial incentives, career progress or cross-cultural development, were much less important to UNORG staff. While over time, family, work-life balance, security and health considerations had an impact in making staff less willing to work in hardship locations, these were generally less important drivers than the mission of the IGO and the wish to help people. Overall, the knowing why of staff in the field in the IGO was highly distinct from that of MNC expatriates - it challenges the applicability of the findings of research into key personal motivators in 


\section{DEVELOPMENT AND TRANSFER OF CAREER CAPITAL}

MNCs conducted by Hippler (2009) or Stahl et al., (2002) and extends some of the insights of faith-based humanitarian agencies to IGOs (Oberholster et al., 2013).

Table 5 also shows that many staff in UNORG did not perceive that their key motivations and knowing why was transferable between head office and duty station. Not only were individuals' duty station capabilities less useful in the head office, most interviewees also felt that the organizational center, located in a major city of a highly developed, rich country, was too far away from the recipients of food aid. Many simply did not want to work in the head office and actively pursued a permanently internationally mobile working life in a variety of duty stations. In terms of organizational rationale, cross-border moves happened because working in the field was a 'rite of passage'. Given the difficulties in transferring knowing how and the predominant focus of knowing why on working in the field the organizational benefits of this approach are unclear and do not seem to be aligned with those outlined in the MNC literature (Edström \& Galbraith, 1977; Scullion \& Collings, 2011). The active avoidance of the organizational center and its impact on the careers of staff is not sufficiently explored in the literature (Dickmann \& Doherty, 2008).

In terms of knowing whom there are some similarities between MNCs and this IGO. The host country networking advantages are both available to MNC and IGO expatriates, supporting the argument developed by Berthoin-Antal (2001). Within both MNCs and this IGO, developing and transferring international networks was, at times, useful for delivering one's work (Jokinen, 2010). However, with respect to building and transferring networks for internal career progression it was clear that working in a field station was not beneficial. This is in contrast to the MNC literature that often identifies internal career progression benefits from working abroad (Doherty \& Dickmann, 2012). The effects of networking activities and individual career strategies are not well understood (Reiche et al., 2011; Benson \& Pattie, 2008). 
DEVELOPMENT AND TRANSFER OF CAREER CAPITAL

\section{Most Professionals in the IGO Pursued Humanitarian Careers}

We have seen above that ICs are characterized through interdependence and self-reinforcement of the three ways of knowing (Lamb \& Sutherland, 2010). Self-reinforcement occurs over time so that transferability is important (Khapova et al., 2007; Jokinen 2010) and emerging evidence from MNCs shows that all three areas of the IC concept are seen to benefit in the very longterm (Dickmann, Suutari, Brewster, Mäkelä, Tanskanen \& Tornikoski: forthcoming). As career capital maximization is recommended (Inkson \& Arthur, 2001) intelligent careerists should therefore invest in all three career capital areas. They should seek social contacts which enable them to do their work and advance in their careers; should develop competencies that are useful now and in their future roles and should pursue their own drivers in relation to what they want to achieve in their lives through work.

The interviews showed that a minority behaved like intelligent careerists and benefited from networking with central and powerful actors, head office-specific learning and increased promotion opportunities in a family-friendly and secure environment. In contrast to these so called 'intelligent careerists' (Inkson \& Arthur, 2001), we found a majority of interviewees (13) pursuing a humanitarian career approach. The majority of the IGO interviewees have chosen neither to maximize their social capital nor to concentrate on acquiring the specific capabilities that were associated with the key positions (and promotions) in the head office. They acquired skills that were difficult to transfer to the head office. It would be wrong to argue that they were not interested in their careers, it was simply less important to them than humanitarian assistance. The maximization of their knowing why with much less regard for networks and capabilities is likely to lead to operations-focused, field-based careers. Because of the different elements that were important in the diverse career capital areas - their 'humanitarian' drivers would encourage local networking and the acquisition of capabilities 


\section{DEVELOPMENT AND TRANSFER OF CAREER CAPITAL}

centered around duty station operations, their 'intelligent career' drivers would stress head office networking and the acquisition of skills that are best learnt in the head office - the career capital areas did not reinforce each other with respect to career progression. These internal dissonances are not well conceptualized in the IC framework which assumes that all three areas reinforce themselves.

In stark contrast to the description of people not pursuing intelligent careers (Inkson \& Arthur, 2001), these humanitarian careerists were committed to the mission of their organization and were willing to learn and network extensively in order to get their front-line jobs done. Individuals were more likely to sacrifice intelligent career behavior in favor of following their key motivations, akin to a calling (Dobrow \& Tosti-Kharas, 2012). It might be speculated that in the humanitarian sector where the head office - field station divide is strong and transferability of career capital is difficult and where (many) individuals follow their drive to help individuals (Oberholster et al., 2013), the humanitarian form of career behavior may be prevalent.

Our contribution to the literature is to show that the development and transferability between organizational center and foreign operating units of career capital is radically distinct between MNCs and IGOs. Our deviant IGO case has illuminated that career capital development and transfer differs substantially from that of MNCs. Amongst the consequences is that committed and hard-working humanitarian careerists may not have the incentive nor the willingness to maximize their specific knowing how and knowing whom career capital geared towards career advancement. These scenarios are not outlined in the specification of the IC framework and we call for a context-sensitive refinement.

\section{Limitations}




\section{DEVELOPMENT AND TRANSFER OF CAREER CAPITAL}

The qualitative research suffers from well-known limitations that impact the generalizability of findings. We only studied UNORG and further research in other IGOs is needed. Caution is also needed in extending the qualitative insights to staff on lower hierarchical levels in IGOs as we interviewed only individuals who were on managerial grades. Our study employed a broad concept of career capital but it is impossible to claim that the categories are collectively exhaustive. Moreover, as with many studies, the selection of interviewees was non-random and the interviews relied on the cooperation of individuals which lead to a limitation to the generalizability of the findings. Thus, the authors urge the readers to be careful in interpreting and applying the findings presented.

\section{Practical Implications}

Our findings challenge the traditional organizational expatriation reasons and add nuances to the relationship head office - foreign affiliate. In this IGO coordination, managerial development, knowledge management and careers follow radically different patterns which are not adequately reflected in IHRM, international mobility and careers literature (Cappellen \& Janssens, 2010; Edström \& Galbraith, 1977; Haslberger \& Brewster, 2009; Sanchez, Spector \& Cooper, 2000).

Some managerial implications are outlined below. Understanding the key drivers of IGO staff and their tendencies towards UN-intelligent careers would be helpful for HR decisions. These could have, first, a bearing on resourcing strategies and selection criteria (Anderson, 2005; Oberholster et al., 2013). Insights regarding UN-intelligent career orientations could be a selection factor with regards to head office or field station work (Cerdin \& Dickmann, 2011).

Second, talent development and careers paths might benefit from rethinking the dictum of 'rite of passage' that implies that every professional staff member needs to be highly mobile. 


\section{DEVELOPMENT AND TRANSFER OF CAREER CAPITAL}

Career management should acknowledge the low skills and knowledge transferability. Considering the 'case' for expatriation may reveal limited organizational advantages and may lead to dual (head office and field station) career paths offered by the IGO.

Third, with respect to structural choices, organizations in the humanitarian sector have moved to a higher degree of integration (Dickmann et al., 2010; Lindenberg \& Bryant, 2001). Increased centralization of policy setting, advocacy, fund-raising, etc., will increase the barriers to competency transferability between head office and field station. This increases the likelihood of dual structures such as operational field and strategic head office humanitarian careers.

Fourth, reward policies for people working quasi-permanently in hardship stations may be refined if organizations do not develop dual head office - field station career structures. While they currently incorporate benefits such as rest and recuperation $(R \& R)$ times, they may factor in the implicit career sacrifice that UN-intelligent careerists accept.

Overall, organizational branding, attraction, development, career management, reward and retention activities may take account of the key drivers and behaviors of individuals. This implies that the complex balancing of humanitarian versus career interests needs to be assessed and managed.

\section{Conclusions and Future Research Directions}

A contribution of this study is that it identifies highly distinct career capital accumulation and transfer patterns between MNCs and IGOs. The data on the distinct IC acquisition patterns in MNCs and foreign units indicates the importance of specific organizational context and location. Insights from the international mobility literature cannot simply be extended to IGOs. In contrast to careers in general, the reinforcement effects between the different career capital areas were substantially reduced, the transfer to other locations was more limited and 


\section{DEVELOPMENT AND TRANSFER OF CAREER CAPITAL}

humanitarian careerists did not strive to maximize all three ways of knowing. Instead, they often preferred to concentrate on their humanitarian interests to the detriment of progressionrelevant knowing whom and knowing how. This refines our theoretical insights developed in the IC literature (Inkson \& Arthur, 2001) implying that a uniform call for career capital development of all three ways of knowing should be reconsidered.

While acknowledging the psychological impact on decision-making (Parker et al., 2009), the IC concept does little to clarify the impact that rational and emotional influence factors have on career decisions and so leaves the potential tensions within and between career capital areas little specified. Tensions within knowing why - for instance between working towards humanitarian aid and pursuing personal promotion goals - are not explored sufficiently. In addition, potential tensions between gaining valuable networks in the organization's center versus developing one's work-related competencies are also less investigated.

A theoretical contribution of this study is, therefore, to call for a further refinement of the assumptions, depiction and application of the IC concept and to encourage the further development of the IC framework and its nuancing across sectors. We call for research that focuses on assessing the interrelationships between the three career capital areas and to explore the (sectoral, national, organizational) context of how global careerists behave. Jokinen et al's., (2008) measures of career capital and the work by Briscoe \& Hall (2006) or Baruch (2014) to assess protean career orientations through measuring values-driven and self-directed career management may be useful starting points.

Our research does not only confirm the importance of social capital and work-related competencies, it reminds us to pay attention to the wider context of sector and organizational structures and operational needs. Whilst it is obvious that many of the poor and needy in the 


\section{DEVELOPMENT AND TRANSFER OF CAREER CAPITAL}

world benefit from humanitarian careerists - it would be important for academia, organizations and individuals to understand them better. 
DEVELOPMENT AND TRANSFER OF CAREER CAPITAL

\section{References}

Ahmad, M. M. (2007). The careers of NGO field-workers in Bangladesh. Nonprofit Management \& Leadership, 17(3), 349-365. doi:10.1002/nml.154

Al Ariss, A., \& Syed, J. (2011). Capital mobilization of skilled migrants: A relational perspective. British Journal of Management, 22(2), 286-304. doi:10.1111/j.14678551.2010.00734.X

Anderson, B. A. (2005). Expatriate selection: Good management or good luck? International Journal of Human Resource Management, 16(4), 567-583. doi:10.1080/09585190500051647

Andreason, A., \& Kinner, K. (2005). Repatriation adjustment problems and the successful reintegration of expatriates and their families. Journal of Behavioral and Applied Psychology, 6, 109-126.

Andresen, M., Biemann, T., \& Pattie, M. W. (2015). What makes them move abroad? Reviewing and exploring differences between self-initiated and assigned expatriation. The International Journal of Human Resource Management, 26(7), 932-947.

Anheier, H., \& Themudo, N. (2005). The internationalisation of the nonprofit sector. In R. D. Herman, \& Associates (Eds.), The Jossey-Bass Handbook of Nonprofit Leadership and Management, 2nd Edition (pp. 102-127). Chichester: John Wiley \& Sons.

Arthur, M. B., Claman, P. H., \& De Fillippi, R. J. (1995). Intelligent enterprise, intelligent $\begin{array}{lllll}\text { careers. Academy of } & \text { Management }\end{array}$ doi:10.5465/AME.1995.9512032185

Arthur, M. B., Khapova, S. N., \& Wilderom, C. P. M. (2005). Career success in a boundaryless career world. Journal of Organizational Behavior, 26(2), 177-202. doi:10.1002/job.290

Arthur, M. B., \& Rousseau, D. M. (1996). A career lexicon for the 21st century. Academy of Management Executive, 10(4), 28-39. doi:10.5465/AME.1996.3145317 


\section{DEVELOPMENT AND TRANSFER OF CAREER CAPITAL}

Bagdadli, S., Solari, L., Usai, A., \& Grandori, A. (2003). The emergence of career boundaries in unbounded industries: Career odysseys in the Italian new economy. International Journal of Human Resource Management, 14(5), 788-808. doi:10.1080/0958519032000080802

Bartlett, C., \& Ghoshal, S. (1998). Managing across borders, $2^{\text {nd }}$ Edition. London: Hutchinson Business Books.

Baruch, Y. (2014). The development and validation of a measure for protean career orientation. The International Journal of Human Resource Management, 25(19), 2702-2723.

Baruch, Y., \& Altman, Y. (2002). Expatriation and repatriation in MNCS: A taxonomy. Human Resource Management, 41(2), 239.

Baruch, Y., Dickmann, M., Altman, Y., \& Bournois, F. (2013). Exploring international work: Types and dimensions of global careers. International Journal of Human Resource Management, 24(12), 2369-2393. doi:10.1080/09585192.2013.781435

Benson, G. S., \& Pattie, M. (2008). Is expatriation good for my career? The impact of expatriate assignments on perceived and actual career outcomes. The International Journal of Human Resource Management, 19(9), 1636-1653.

Berthoin-Antal, A. (2001). Expatriates' contributions to organizational learning. Journal of General Management, 26(4), 62-84.

Biemann, T., \& Braakmann, N. (2013). The impact of international experience on objective and subjective career success in early careers. The International Journal of Human Resource Management, 24(18), 3438-3456.

Boies, K., \& Rothstein, M. G. (2002). Managers' interest in international assignments: The role of work and career satisfaction. International Journal of Intercultural Relations, 26(3), 233-253. doi:10.1016/S0147-1767(02)00002-0 


\section{DEVELOPMENT AND TRANSFER OF CAREER CAPITAL}

Bourdieu, P. (1986). The forms of capital. In J. C. Richardson (Ed.), Handbook of theory and research for the sociology of education (pp. 241-258). London: Greenwood Press.

Bozkurt, Ö., \& Mohr, A. T. (2011). Forms of cross-border mobility and social capital in multinational enterprises. Human Resource Management Journal, 21(2), 138-155. doi:10.1111/j.1748-8583.2010.00147.x

Brewster, C., \& Suutari, V. (2005). Global HRM: Aspects of a research agenda. Personnel Review, 34(1), 5-21. doi:10.1108/00483480510571851

Briscoe, J., \& Hall, D. T. (2006). The interplay of boundaryless and protean careers: Combinations and implications. Journal of Vocational Behavior, 69(1), 4-18. doi:10.1016/j.jvb.2005.09.002

Briscoe, D. R., \& Schuler, R. S. (2004). International human resource management: Policy and practice for the global enterprise (Vol. 5). Psychology Press.

Bryman, A. \& Bell, E. (2015). Business Research Methods, $4^{\text {th }}$ Edition, Oxford: Oxford University Press.

Caligiuri, P. (2012). Cultural agility: Building a pipeline of successful global professionals. San Francisco: Jossey-Bass.

Caligiuri, P., \& Di Santo, V. (2001). Global competence: What is it, and can it be developed through global assignments? Human Resource Planning, 24(3), 27-35.

Caligiuri, P., \& Tarique, I. (2009). Predicting effectiveness in global leadership activities. Journal of World Business, 44(3), 336-346. doi:10.1016/j.jwb.2008.11.005

Cappellen, T., \& Janssens, M. (2010). The career reality of global managers: An examination of career triggers. International Journal of Human Resource Management, 21(11), 18841910. doi:10.1080/09585192.2010.505090 


\section{DEVELOPMENT AND TRANSFER OF CAREER CAPITAL}

Cerdin, J.-L., \& Bird, A. (2008). Careers in a global context. In M. Harris (Ed.), Handbook of research in international human resource management (pp. 207-227). New York, NY: Lawrence Erlbaum Associates.

Cerdin, J.-L., \& Dickmann, M. (2011). Expatriation success in an inter-governmental organization. Best Paper Proceedings of the 2011 Meeting of the Academy of Management, San Antonio, Texas, USA. doi:10.5465/AMBPP.2011.65869485

Cerdin, J.-L., \& Le Pargneux, M. (2009). Career and international assignment fit: Toward an integrative model of success. Human Resource Management, 48(1), 5-25.

Dabic, M., González-Loureiro, M., \& Harvey, M. (2015). Evolving research on expatriates: what is 'known'after four decades (1970-2012). The International Journal of Human Resource Management, 26(3), 316-337.

DeFillippi, R., \& Arthur, M. (1994). The boundaryless career: a competency-based perspective. Journal of Organizational Behavior, 15(3), 307-324.

Dickmann, M., \& Baruch, Y. (2011). Global careers. London: Routledge.

Dickmann, M., \& Doherty, N. (2008). Exploring the career capital impact of international assignments within distinct organizational contexts. British Journal of Management, 19(2), 145-161. doi:10.1111/j.1467-8551.2007.00539.x

Dickmann, M., \& Doherty, N. (2010). Exploring organisational and individual career goals, interactions and outcomes of international assignments. Thunderbird International Review, 52(4), 313-324. doi:10.1002/tie.20353

Dickmann, M., Doherty, N., Mills, T., \& Brewster, C. (2008). Why do they go? Individual and corporate perspectives on the factors influencing the decision to accept an international assignment. International Journal of Human Resource Management, 19(4), 731-751. doi:10.1080/09585190801953749 


\section{DEVELOPMENT AND TRANSFER OF CAREER CAPITAL}

Dickmann, M., \& Harris, H. (2005). Developing career capital for global careers: The role of international assignments. Journal of World Business, 40(4), 399-408.

Dickmann, M., Parry, E., Emmens, B., \& Williamson, C. (2010). Engaging tomorrow's global humanitarian leaders today. (Report for ELHRA (Enhancing Learning and Research for Humanitarian Assistance)). London: People in Aid.

Dickmann, M., Suutari, V., Brewster, C., Mäkelä, L., Tanskanen, J. and Tornikoski, C. Expatriation and Career Success: Assessing the Development of Career Capital over Time. The International Journal of Human Resource Management: forthcoming.

Dobrow, S., \& Tosti-Kharas, J. (2012). Listen to your heart? Calling and receptivity to career advice. Journal of Career Assessment, 20(3), 264-280. doi:10.1177/106907271143441

Doherty, N. T., \& Dickmann, M. (2012). Measuring the return on investment in international assignments: An action research approach. International Journal of Human Resource Management, 23(16), 3434-3454. doi:10.1080/09585192.2011.637062

Dowling, P., Festing, M. \& Engle, A. (2008). International human resource management: Managing people in a multinational context. London: Thomson Learning.

Edström, A., \& Galbraith, J. R. (1977). Transfer of managers as a coordination and control strategy in multinational organizations. Administrative Science Quarterly, 22(2), 248263.

Edwards, T., Colling, T., \& Ferner, A. (2007). Conceptual approaches to the transfer of employment practices in multinational companies: An integrated approach. Human Resource Management Journal, 17(3), 201-217. doi:10.1111/j.1748-8583.2007.00042.x

Emigh, R. (1997). The power of negative thinking: The use of negative case methodology in the development of sociological theory. Theory and Society, 26(5), 649-684. 


\section{DEVELOPMENT AND TRANSFER OF CAREER CAPITAL}

Emmerik, I. H., \& Euwema, M. C. (2009). The international assignments of peacekeepers: What drives them to seek future expatriation? Human Resource Management, 48(1), 135151.

Farh, C. I. C., Bartol, K. M., Shapiro, D. L., \& Shin, J. (2010). Networking abroad: A process model of how expatriates form support ties to facilitate adjustment. Academy of Management Review, 35(3), 434-454. doi:10.5465/AMR.2010.51142246

Fee, A., \& Gray, S. J. (2013). Transformational learning experiences of international development volunteers in the Asia-Pacific: The case of a multinational NGO. Journal of World Business, 48(2), 196-208. doi:10.1016/j.jwb.2012.07.004

Feldman, D. C., \& Thomas, D. C. (1992). Career management issues facing expatriates. Journal of International Business Studies, 23(2), 271-293.

Ferner, A., \& Edwards, P. (1995). Power and diffusion of organizational change within multinational enterprises. European Journal of Industrial Relations, 1(2), 229-257. doi:10.1177/095968019512004

Granrose, C. S., \& Baccili, P. A. (2006). Do psychological contracts include boundaryless or protean careers? Career Development International, 11(2), 163-182.

doi: $10.1108 / 13620430610651903$

Greenhaus, J. H., Callanan, G. A., \& DiRenzo, M. (2008). A boundaryless perspective on careers. In J. Barling (Ed.), Handbook of organizational behavior (pp. 277-299). Thousand Oaks, CA.: Sage.

Greenhaus, J. H., Callanan, G. A., \& Godshalk, V. M. (2010). Career management, $4^{\text {th }}$ Edition. $^{\text {. }}$ Thousand Oaks, CA.: Sage.

Gupta, A. K., \& Govindarajan, V. (2000). Knowledge flows within multinational corporations. Strategic Management Journal, 21(4), 473.

Hall, D. T. (1976). Careers in organizations. Pacific Palisades, CA.: Goodyear. 


\section{DEVELOPMENT AND TRANSFER OF CAREER CAPITAL}

Hall, D. T. (1996). Protean careers of the 21st century. Academy of Management Executive, 10(4), 8-16. doi:10.5465/AME.1996.3145315

Harvey, M., Speier, C., \& Novicevic, M. M. (1999). The role of inpatriation in global staffing. International Journal of Human Resource Management, 10(3), 459-476.

Harzing, A.-W. (1999). Managing the multinationals - an international study of control mechanisms. Cheltenham, UK: Edward Elgar.

Haslberger, A. (2005). The complexities of expatriate adaptation. Human Resource Management Review, 15(2), 160-180. doi:10.1016/j.hrmr.2005.07.001

Haslberger, A., \& Brewster, C. (2009). Capital gains: Expatriate adjustment and the psychological contract in international careers. Human Resource Management, 48(3), 379-397.

Haslberger, A., Brewster, C., \& Hippler, T. (2013). The dimensions of expatriate adjustment. Human Resource Management, 52(3), 333-351.

Hippler, T. (2009). Why do they go? Empirical evidence of employees' motives for seeking or accepting relocation. International Journal of Human Resource Management, 20(6), 1381-1401. doi:10.1080/09585190902909889

Hudson, S., \& Inkson, K. (2006). Volunteer overseas development workers: The hero's adventure and personal transformation. Career Development International, 11(4), 304320. doi:10.1108/13620430610672522

Ibarra, H., \& Deshpande, P. (2007). Networks and identities: Reciprocal influences on career processes and outcomes. In H. Gunz, \& M. Peiperl (Eds.), Handbook of career studies (pp. 262-282). London: Sage.

Inkson, K., \& Arthur, M. B. (2001). How to be a successful career capitalist. Organizational Dynamics, 30(1), 48-61. 


\section{DEVELOPMENT AND TRANSFER OF CAREER CAPITAL}

Jokinen, T. (2010). Development of career capital through international assignments and its transferability to new contexts. Thunderbird International Business Review, 52(4), 325336. doi:10.1002/tie.20351

Jokinen, T., Brewster, C., \& Suutari, V. (2008). Career capital during international work experiences: Contrasting self-initiated expatriate experiences and assigned expatriation. International Journal of Human Resource Management, 19(6), 979-998. doi:10.1080/09585190802051279

Jones, C., \& Lichtenstein, B. (2000). The 'architecture' of careers: How career competencies reveal firm dominant logic in professional services. In M. Peiperl, M. Arthur, R. Goffee \& T. Morris (Eds.), Career Frontiers. Oxford, UK: Oxford University Press.

Khapova, S. N., Arthur, M. B., \& Wilderom, C. P. M. (2007). The subjective career in the knowledge economy. Handbook of career studies. Los Angeles, CA.: Sage.

King, N. (1998). Template analysis. In G. Symon, \& C. Cassell (Eds.), Qualitative methods and analysis in organizational research: A practical guide (pp. 118-134). London: Sage Publications Ltd.

Kohonen, E. (2005). Developing global leaders through international assignments: An identity construction perspective. Personnel Review, 34(1), 22-36. doi:10.1108/00483480510571860

Kraimer, M. L., Shaffer, M. A., Harrison, D. A., \& Ren, H. (2012). No place like home? An identity strain perspective on repatriate turnover. Academy of Management Journal, 55(2), 399-420.

Lamb, M., \& Sutherland, M. (2010). The components of career capital for knowledge workers in the global economy. International Journal of Human Resource Management, 21(3), 295-312. doi:10.1080/09585190903546839 


\section{DEVELOPMENT AND TRANSFER OF CAREER CAPITAL}

Lazarova, M. B., \& Cerdin, J. (2007). Revisiting repatriation concerns: Organizational support versus career and contextual influences. Journal of International Business Studies, 38(3), 404-429.

Lindenberg, M., \& Bryant, C. (2001). Going global: Transforming relief and development NGOs. Bloomfield, CT: Kumarian Press Inc.

Lips-Wiersma, M., \& Hall, D. T. (2007). Organizational career development is not dead: A case study on managing the new career during organizational change. Journal of Organizational Behavior, 28(6), 771-792.

Maddux, W. W., Adam, H., \& Galinsky, A. D. (2010). When in Rome...learn why the romans do what they do: How multicultural learning experiences enhance creativity. Personality and Social Psychology Bulletin, 36(6), 731-741.

Mäkelä, K., Bjorkman, I., \& Ehrnrooth, M. (2009). MNC subsidiary staffing architecture: Building human and social capital within the organisation. International Journal of Human Resource Management, 20(6), 1273-1290. doi:10.1080/09585190902909814

Mäkelä, K., \& Suutari, V. (2013). The social capital of traditional and self-initiated expatriates. In V. Vaiman, \& A. Haslberger (Eds.), Talent management of self-initiated expatriates: A neglected source of global talent (pp. 256-277). New York: Palgrave-Macmillan.

McKinlay, A. (2002). 'Dead selves': The birth of the modern career. Organization, 9(4), 595.

Merlot, E. S., \& De Cieri, H. (2012). The challenges of the 2004 Indian ocean tsunami for strategic international human resource management in multinational nonprofit enterprises. International Journal of Human Resource Management, 23(7), 1303-1319. doi:10.1080/09585192.2011.610337

Newell, H. \& Dopson, S. (1996). Muddle in the middle: organizational restructuring and middle management careers. Personnel Review 25(4): 4-20. 


\section{DEVELOPMENT AND TRANSFER OF CAREER CAPITAL}

Oberholster, A., Clarke, R., Bendixen, M., \& Dastoor, B. (2013). Expatriate motivation in religious and humanitarian non-profit organizations. Journal of Global Mobility, 1(1), 727. doi:JGM-09-2012-0007

Parker, P., Khapova, S., \& Arthur, M. (2009). The intelligent career framework as a basis for interdisiplinary inquiry. Journal of Vocational Behavior, 75(3), 291-302. doi:10.1016/j.jvb.2009.04.001

Piekkari, R., Welch, C., \& Paavilainen, E. (2009). The case study as disciplinary convention: Evidence from international business journals. Organizational Research Methods, 12(3), $567-589$.

Quinn, J. B. (1992). Intelligent enterprise. New York: Free Press.

Reiche, B. S. (2006). The inpatriate experience in multinational corporations: An exploratory case study in Germany. The International Journal of Human Resource Management, 17(9), 1572-1590.

Reiche, B. S., Harzing, A., \& Kraimer, M. L. (2009). The role of international assignees' social capital in creating inter-unit intellectual capital: A cross-level model. Journal of International Business Studies, 40(3), 509-526. doi:10.1057/jibs.2008.86

Reiche, B. S., Kraimer, M. L., \& Harzing, A. (2011). Why do international assignees stay? An organizational embeddedness perspective. Journal of International Business Studies, 42(4), 521-544. doi:10.1057/jibs.2011.5

Richardson, J. (2009). Geographic flexibility in academia: A cautionary note. British Journal of Management, 20, S160-S170. doi:10.1111/j.1467-8551.2008.00641.x

Sanchez, J. I., Spector, P. E., \& Cooper, C. L. (2000). Adapting to a boundaryless world: A developmental expatriate model. Academy of Management Executive, 14(2), 96-106. doi:10.5465/AME.2000.3819309 


\section{DEVELOPMENT AND TRANSFER OF CAREER CAPITAL}

Schein, E. H. (1978). Career dynamics: Matching individual and organizational needs. Reading, MA.: Addison Wesley.

Scullion, H., \& Collings, D. (2011). Global talent management. New York: Routledge.

Shaffer, M. A., Kraimer, M. L., Chen, Y., \& Bolino, M. C. (2012). Choices, challenges, and career consequences of global work experiences: A review and future agenda. Journal of Management, 38(4), 1282-1327. doi:10.1177/0149206312441834

Sparrow, P. (2006). Global knowledge management and HRM. In G. Stahl, \& I. Bjorkman (Eds.), Handbook of research in international human resource management. Cheltenham, UK: Edward Elgar.

Stahl, G. K., Miller, E. L., \& Tung, R. L. (2002). Toward the boundaryless career: A closer look at the expatriate career concept and the perceived implications of an international assignment. Journal of World Business, 37(3), 216-227.

Stenhouse, L. (1980). The Study of Samples and the Study of Cases*. British Educational Research Journal, 6(1), 1-6.

Sullivan, S. E., \& Arthur, M. (2006). The evolution of the boundaryless career concept: Examining physical and psychological mobility. Journal of Vocational Behavior, 69(1), 19-29. doi:10.1016/j.jvb.2005.09.001

Sullivan, S. E., \& Baruch, Y. (2009). Advances in career theory and research: A critical review and agenda for future exploration. Journal of Management, 35(6), 1542-1571. doi:10.1177/0149206309350082

Suutari, V., \& Mäkelä, K. (2007). The career capital of managers with global careers. Journal of Managerial Psychology, 22(7), 628-648. doi:10.1108/02683940710820073

Tams, S., \& Arthur, M. B. (2010). New directions for boundaryless careers: Agency and interdependence in a changing world. Journal of Organizational Behavior, 31(5), 629646. 


\section{DEVELOPMENT AND TRANSFER OF CAREER CAPITAL}

Thomas, D. C., \& Inkson, K. (2004). Cultural intelligence: People skills for global business. San Francisco, USA: Berret-Koehler.

Toh, S. M., \& DeNisi, A. S. (2007). Host country nationals as socializing agents: A social identity approach. Journal of Organizational Behavior, 28(3), 281-301.

Toomey, E. (2010). Expatriates in transition. Doctoral dissertation, SAID Business School, University of Oxford.

Tung, R. L. (1998). American expatriates abroad: From neophytes to cosmopolitans. Journal of World Business, 33(2), 125.

Wang, X., \& Kanugo, R. N. (2004). Nationality, social network and psychological well-being: Expatriates in china. International Journal of Human Resource Management, 15(4), 775793. doi:10.1080/0958519042000192942

Wolff, H., \& Moser, K. (2009). Effects of networking on career success: A longitudinal study. Journal of Applied Psychology, 94(1), 196-206. doi:10.1037/a0013350

Yan, A., Zhu, G., \& Hall, D. T. (2002). International assignments for career building: A model of agency relationships and psychological contracts. Academy of Management Review, 27(3), 373-391. doi:10.5465/AMR.2002.7389910

Yao, C. (2014). The impact of cultural dimensions on Chinese expatriates' career capital. The International Journal of Human Resource Management, 25(5), 609-630.

Yin, R. K. (2009). Case study research design and methods, $4^{\text {th }}$ Edition. London: Sage.

Zikic, J., Bonache, J., \& Cerdin, J. (2010). Crossing national boundaries: A typology of qualified immigrants' career orientations. Journal of Organizational Behavior, 31(5), 667-686. 
DEVELOPMENT AND TRANSFER OF CAREER CAPITAL

Table 1: Overview of professional staff interviewees (names anonymized)

\begin{tabular}{|c|c|c|c|c|c|c|c|c|}
\hline $\begin{array}{c}\text { Interviewee } \\
\text { number }\end{array}$ & Age & $\begin{array}{l}\text { National } \\
\text { origin }\end{array}$ & $\begin{array}{c}\text { Gen } \\
\text {-der }\end{array}$ & $\begin{array}{l}\text { Hier- } \\
\text { archical } \\
\text { grade }\end{array}$ & $\begin{array}{l}\text { Planned } \\
\text { Length } \\
\text { of } \\
\text { Current } \\
\text { Assign } \\
\text { ment }\end{array}$ & $\begin{array}{l}\text { Pattern of } 3 \\
\quad \text { last } \\
\text { assignment } \\
\quad \text { s with } \\
\text { current last }\end{array}$ & Role & Family \\
\hline Akemi, 1 & 36 & Japan & $F$ & P3 & 4 ys & $\begin{array}{l}\text { Butan, Sri } \\
\text { Lanka, } \\
\text { Japan }\end{array}$ & $\begin{array}{l}\text { Communicati } \\
\text { ons and Donor } \\
\text { Relations }\end{array}$ & Single \\
\hline Kate, 5 & 44 & USA & $\mathrm{F}$ & P5 & 3 ys & $\begin{array}{l}\text { South } \\
\text { Africa, } \\
\text { Tanzania, } \\
\text { Malawi }\end{array}$ & $\begin{array}{l}\text { Acting } \\
\text { Country } \\
\text { Director }\end{array}$ & $\begin{array}{l}\text { Yes, husband, } \\
\text { no children }\end{array}$ \\
\hline Adelara, 7 & 44 & Nigeria & $\mathrm{F}$ & P5 & 4 ys & $\begin{array}{l}\text { Zimbabwe, } \\
\text { South } \\
\text { Africa, } \\
\text { Kenya }\end{array}$ & $\begin{array}{l}\text { Senior } \\
\text { Logistics } \\
\text { Officer }\end{array}$ & $\begin{array}{l}\text { Yes, husband, } \\
\text { no children }\end{array}$ \\
\hline Susanne, 15 & 34 & $\begin{array}{l}\text { German/ } \\
\text { Hungarian }\end{array}$ & $\mathrm{F}$ & $\begin{array}{l}\mathrm{P} 2 \text { (on } \mathrm{P} 3 \\
\text { post) }\end{array}$ & 4 ys & $\begin{array}{l}\text { Madagascar, } \\
\text { HQ, Syria }\end{array}$ & Prog Officer & $\begin{array}{l}\text { Yes, husband, } \\
1 \text { child }\end{array}$ \\
\hline Winnie, 8 & 52 & Zambia & $\mathrm{F}$ & D1 & 4 ys & $\begin{array}{l}\text { Mozambiqu } \\
\text { e, South } \\
\text { Africa, HQ }\end{array}$ & $\begin{array}{l}\text { Director } \\
\text { Vulnerability } \\
\text { Assessment }\end{array}$ & $\begin{array}{l}\text { Yes, } 2 \\
\text { children, is } \\
\text { divorced }\end{array}$ \\
\hline Christine, 3 & 34 & $\begin{array}{l}\text { Swedish/ } \\
\text { Chinese }\end{array}$ & $\mathrm{F}$ & P3 & 4 ys & $\begin{array}{l}\text { HQ, Sudan, } \\
\text { HQ }\end{array}$ & $\begin{array}{l}\text { Inter-Agency } \\
\text { Relations }\end{array}$ & $\begin{array}{l}\text { Yes recently } \\
\text { married, no } \\
\text { children }\end{array}$ \\
\hline Na-yung, 16 & 51 & US & $\mathrm{F}$ & P4 & 6 ys & HQ & $\begin{array}{l}\text { Shipping } \\
\text { Officer }\end{array}$ & $\begin{array}{l}\text { Yes, husband, } \\
\text { no children }\end{array}$ \\
\hline Monique, 11 & 33 & France & $\mathrm{F}$ & $\mathrm{P} 2$ & 6 ys & $\begin{array}{l}\text { Burkina } \\
\text { Faso }\end{array}$ & Aid Officer & Yes, 1 child \\
\hline Nada, 4 & 35 & Albania & $\mathrm{F}$ & P3 & 2 ys & $\begin{array}{l}\text { HQ, Jordan } \\
\text { (operating } \\
\text { in Iraq), } \\
\text { Sudan }\end{array}$ & $\begin{array}{l}\text { Resource } \\
\text { Analyst }\end{array}$ & Single \\
\hline Joao, 6 & 33 & Brazil & M & $\mathrm{P} 2$ & 2 ys & $\begin{array}{l}\text { HQ, } \\
\text { Malawi, } \\
\text { Sudan }\end{array}$ & $\begin{array}{l}\text { Logistics and } \\
\text { Overall Field } \\
\text { Support }\end{array}$ & $\begin{array}{l}\text { Yes, wife, no } \\
\text { children }\end{array}$ \\
\hline Charles, 10 & 44 & Ghana & M & $\begin{array}{l}\mathrm{P} 3 \text { (on a } \\
\mathrm{P} 4 \text { post) }\end{array}$ & 4 ys & $\begin{array}{l}\text { Kuwait, } \\
\text { Liberia, } \\
\text { Sudan }\end{array}$ & $\begin{array}{l}\text { Security } \\
\text { Expert }\end{array}$ & $\begin{array}{l}\text { Yes, wife, } 4 \\
\text { children }\end{array}$ \\
\hline Yomi, 9 & 51 & Uganda & M & $\mathrm{P} 2$ & 3 ys & $\begin{array}{l}\text { HQ, Sudan, } \\
\text { Sierra } \\
\text { Leone }\end{array}$ & $\begin{array}{l}\text { Finance } \\
\text { Officer }\end{array}$ & $\begin{array}{l}\text { Divorced, } 2 \\
\text { children }\end{array}$ \\
\hline Fuad, 12 & 43 & $\begin{array}{l}\text { Burkina } \\
\text { Faso }\end{array}$ & M & P3 & 2 ys & $\begin{array}{l}\text { Angola, } \\
\text { DRC, Chad }\end{array}$ & ICT Officer & $\begin{array}{l}\text { Yes, wife, } 3 \\
\text { children }\end{array}$ \\
\hline Shola, 14 & 58 & Ethiopia & M & $\begin{array}{l}\text { P5 (on a } \\
\text { P4 post) }\end{array}$ & 4 ys & $\begin{array}{l}\text { HQ, Sudan, } \\
\text { Pakistan }\end{array}$ & $\begin{array}{l}\text { Head of } \\
\text { Procurement }\end{array}$ & $\begin{array}{l}\text { Yes, wife, } 2 \\
\text { daughters }\end{array}$ \\
\hline Jaime, 2 & 45 & Peru & M & $\begin{array}{l}\text { P5 (on a } \\
\text { P4 post) }\end{array}$ & 4 ys & $\begin{array}{l}\text { Mozambiqu } \\
\text { e, Tanzania, } \\
\text { Panama }\end{array}$ & $\begin{array}{l}\text { Head of } \\
\text { Regional } \\
\text { Logistics }\end{array}$ & $\begin{array}{l}\text { Yes, wife, } 1 \\
\text { daughter }\end{array}$ \\
\hline Kim, 13 & 35 & $\begin{array}{l}\text { South } \\
\text { Korea }\end{array}$ & $\mathrm{F}$ & P4 & 4 ys & $\begin{array}{l}\text { Zimbabwe, } \\
\text { Colombia, } \\
\text { Philippines }\end{array}$ & $\begin{array}{l}\text { Logistics } \\
\text { Officer }\end{array}$ & $\begin{array}{l}\text { Yes, husband, } \\
\text { no children }\end{array}$ \\
\hline
\end{tabular}

Interviewees who joined in the HQ: 1, 3, 4, 5, 8, 15, 16. All others joined in the field. Half of the interviewees were in duty stations classified as hardship. 


\section{DEVELOPMENT AND TRANSFER OF CAREER CAPITAL}

HR Expert Interviewees: The 13 interviewees included the Head of HRM, her deputy, various HR specialists (for career management, development, HR policy and staff relations), operational experts and interfaces (Chief Operational Officer, Deputy COO, one country director), staff representatives from the professional staff association and other stakeholders (Ombudsman, Grants Manager).

The Focus Group consisted of seven staffing coordinators who work in cooperation with HRM to determine which staff go to which duty stations. In addition to international assignments, they discuss careers progression of professional staff. 
Table 2: Linking interviewee statements to knowing how career capital development in and transfer between head office and field stations

\begin{tabular}{ll}
\hline Knowing How Area & \multicolumn{1}{c}{ Statements } \\
\hline $\begin{array}{l}\text { Technical know- } \\
\text { how }\end{array}$ & $\begin{array}{l}\text { Int 5: I wasn't really prepared for my work in the field. Sure, emotionally it was difficult. But that was not what I meant. I mean it was the real work } \\
\text { in the field that taught me how to organize aid convoys, how to negotiate with government and other stakeholders... And then you have to keep your } \\
\text { calm when some young man points a gun at you. }\end{array}$ \\
\hline $\begin{array}{l}\text { Organizational } \\
\text { culture know-how }\end{array}$ & $\begin{array}{l}\text { Int 6: In [head office], you don't see the beneficiaries....In the city you would not be able to see the beneficiaries, the trucks, the helicopters, the } \\
\text { food. The work in the field is what [UNORG] is about. }\end{array}$ \\
\hline $\begin{array}{l}\text { Intercultural know- } \\
\text { how }\end{array}$ & $\begin{array}{l}\text { Int 13: I can only say I had been travelling a lot and I do speak seven languages, which has certainly helped me a lot in cross-cultural } \\
\text { communications.... Most people come in already with an international background... I certainly did not have to go to Colombia or the Philippines }\end{array}$ \\
& $\begin{array}{l}\text { Int learn about how to interact with people from other cultures... and I very much doubt whether working in [head office] would improve that. } \\
\text { skills and I improved my understanding of global issues and politics. } \\
\text { acumen }\end{array}$ \\
Transfer & $\begin{array}{l}\text { Int 15: Could I apply what I learnt in [the head office] in Madagascar? No, it was a different type of work.... But the knowledge that you acquire in } \\
\text { the field... you can use that in your next location. It is another type of knowledge than sitting in the policy section in headquarters and writing } \\
\text { papers. }\end{array}$ \\
& Int 10: [Head Office] and any of the hardship duty stations are worlds apart... I see little opportunity to use my expertise in [Head Office].
\end{tabular}




\section{DEVELOPMENT AND TRANSFER OF CAREER CAPITAL}

Table 3: Linking interviewee statements to knowing why career capital development in and transfer between head office and field stations

\begin{tabular}{c|c}
\hline $\begin{array}{c}\text { Knowing Why } \\
\text { Area }\end{array}$ & Statements \\
\hline Personal interests & Int 2: It's much more rewarding than working in the head office.... In the field, by definition, you're closer to the people that you actually want to advance their
\end{tabular}

and drivers situation with your work while in [head office] you are geographically but also in your thinking much more detached from reality.

Int 6: In [head office] that was just work. What I want to say is that I could have worked in another organization, even firms like an insurance company. But it did not fulfill me.... Here in Sudan work is hard and I see a lot of suffering but I go to bed with a good conscience.

Career Int 11: I'm committed to [UNORG's] beneficiaries, I'm not committed to [UNORG] as an institution. ... I'm not an [UNORG] fan.

considerations $\quad Q$ : What makes you so sceptical?

A: (Int 11): Um, injustice ... whether you work in [the head office] or not. [The head office] is the key to your career... I really, really would not want to work there [in head office] even though that is better for your career.

Int 15: My own career is not my primary driver. Otherwise, I would be desperately unhappy here [in Syria field office]. Careers depend very much on two things. One, your superior speaks and writes English well and can argue eloquently for your advancement. Two, you build the right connections in [head office]. That should make me desperate to leave for [head office] but I am not... I am here where I am needed.

Financial

considerations

Security and health Int 2: [T] hey tried to kill me in Angola and I manage to speak a few choked words and people recognized that I was the only foreigner to speak their words and

Int 6: The money, I don't need the money. I'm not in this life for money.... I did not get promoted this year although I should have - but I was not because I am out of sight for the key deciders in [the head office]. It was something that upset me for one or two days only. After that, I said, no, it's not a problem. The focus is not the promotion. The focus is the beneficiaries [in the field] and that motivates me. then they leave [sic] me alone.

Q: Did this have an impact on you wanting to work in hardship duty stations?

A. Yes, it made me think..

Family and life- $\quad$ Int 3: I think that having a family is extremely important. You don't want to gamble that away by being in the bush having an interesting experience, even balance iss

Cross-cultural development though you're doing good, but, you know, you can't sacrifice it for life.

Organizational

Pressures

Transfer Int 10: I don't think working abroad has given me many more cultural insights. You see, I had studied abroad and travelled extensively.... It is not really the locations I have worked in...

Head of HRM: " International assignments are a 'rite of passage'

Int 14: When I come to think about my time in [Head Office] I think it was good for the education of my daughters... But it was not good for me, I mean I did not feel motivated. The work was too detached, I was too detached from our beneficiaries. I really felt this was not what I joined [UNORG] for.

Int 4: I enjoyed life in [Head Office], after all [Location] is one of the world's great cities. But work, well, let's say I am not made for bureaucracy.... So, I did not enjoy that aspect... When I then worked in the field again, in Jordan and Iraq and now in Sudan, it was a totally different feeling. I felt far less selfindulgent, ...this [work in the field] gives meaning to my life. 


\section{DEVELOPMENT AND TRANSFER OF CAREER CAPITAL}

Table 4: Linking interviewee statements to knowing whom career capital development in and transfer between head office and field stations

\begin{tabular}{|c|c|}
\hline $\begin{array}{c}\text { Knowing Whom } \\
\text { Area }\end{array}$ & Statements \\
\hline $\begin{array}{l}\text { Host country } \\
\text { networks }\end{array}$ & $\begin{array}{l}\text { Int 7: For my job, definitely the local networking between the stations is useful because we learn from each other. } \\
\text { Q: Do you think working in a hardship location gets sufficient career recognition? } \\
\text { A: (Int 2): No. No... not really. } \\
\text { Int 12: Of course the endorsement of your CD [country director] of your case for promotion is important. But then, there are so many other people in } \\
\text { [head office] involved so that you really need them on your side. }\end{array}$ \\
\hline $\begin{array}{l}\text { International } \\
\text { networks }\end{array}$ & Int 8: All considered working in the field does not help your international contacts - that would be better in [the head office]. \\
\hline $\begin{array}{l}\text { Head office } \\
\text { networks }\end{array}$ & $\begin{array}{l}\text { Int 13: So my personal belief is that your personal career progression really depends on who you know. The key people are in [the head office]. } \\
\text { Int 5: ... start using the networks I have in [the head office] for own professional development... And the minute I did that, well my career changed } \\
\text { overnight. }\end{array}$ \\
\hline Transfer & $\begin{array}{l}\text { Int 9: And then you move on and you make new friends. For me that means that you have new colleagues and the old ones come more and more distant } \\
\text { and you don't really talk to them that much... But for other people in higher positions they seem to be good in keeping their contacts in [Head Office]. } \\
\text { Int 14: Well, this is not such a big organization. I bump into colleagues I have worked with in the past all the time.... Not necessarily local workers, but, } \\
\text { you know, the professional staff who are like me moving around a lot. }\end{array}$ \\
\hline
\end{tabular}


Table 5: Intelligent careers in an IGO: career capital effects in head office (HO) and foreign duty station (DS)

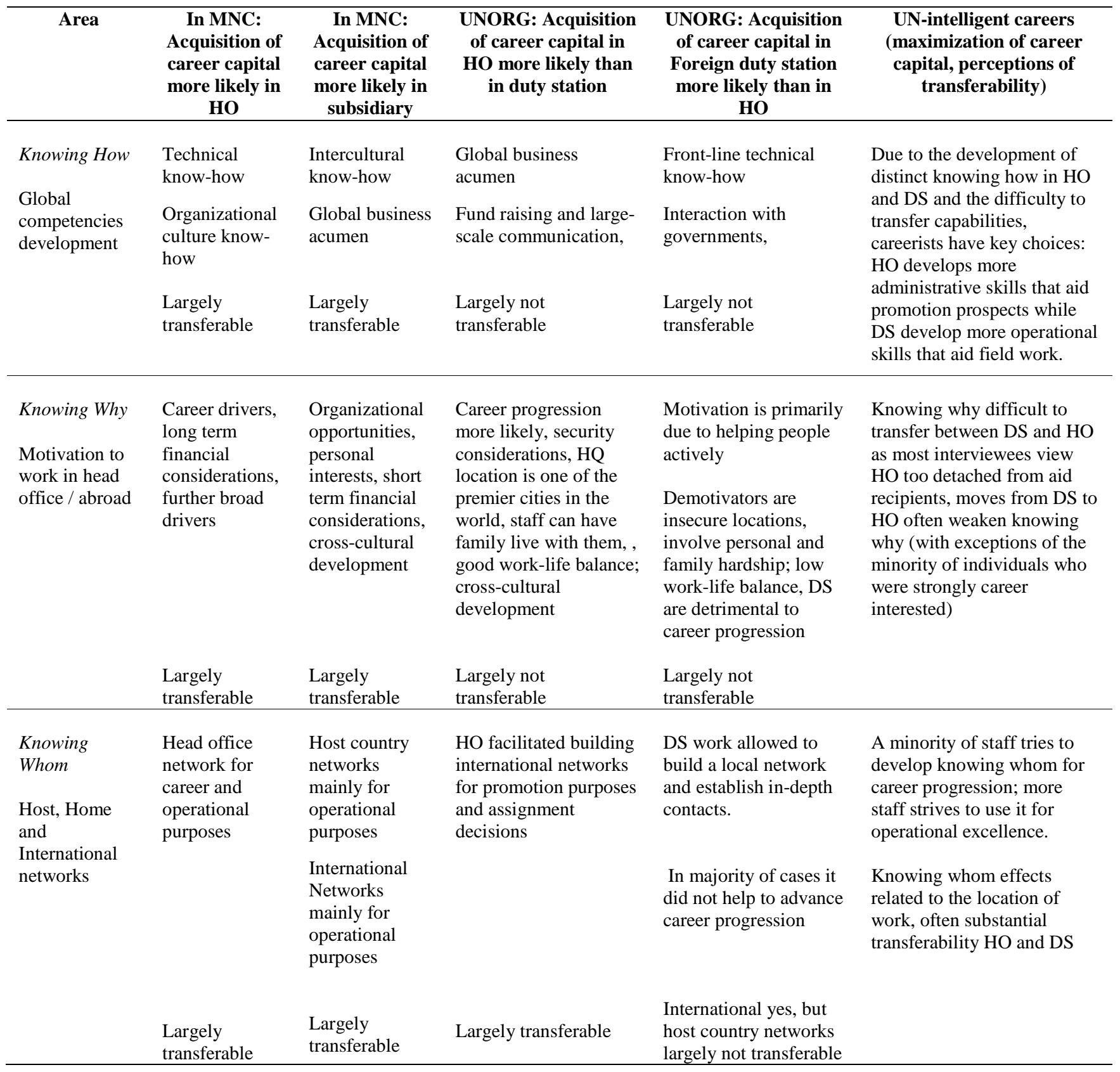

